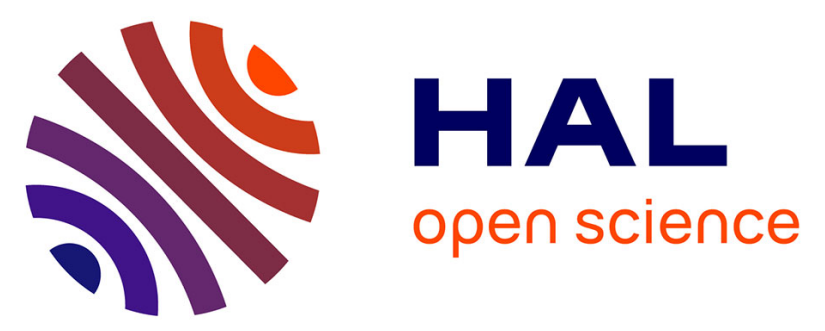

\title{
Risk analysis of ischemic-type biliary lesions after liver transplant using octogenarian donors
}

\author{
Michel Rayar, Giovanni Battista Levi Sandri, Caterina Cusumano, Pauline \\ Houssel-Debry, Christophe Camus, Véronique Desfourneaux, Mohamed \\ Lakehal, B. Meunier, Laurent Sulpice, Karim Boudjema
}

\section{To cite this version:}

Michel Rayar, Giovanni Battista Levi Sandri, Caterina Cusumano, Pauline Houssel-Debry, Christophe Camus, et al.. Risk analysis of ischemic-type biliary lesions after liver transplant using octogenarian donors. Liver Transplantation, 2016, 22 (9), pp.1301-1302. 10.1002/lt.24482 . hal-01373304

\section{HAL Id: hal-01373304 https://hal-univ-rennes1.archives-ouvertes.fr/hal-01373304}

Submitted on 14 Oct 2016

HAL is a multi-disciplinary open access archive for the deposit and dissemination of scientific research documents, whether they are published or not. The documents may come from teaching and research institutions in France or abroad, or from public or private research centers.
L'archive ouverte pluridisciplinaire HAL, est destinée au dépôt et à la diffusion de documents scientifiques de niveau recherche, publiés ou non, émanant des établissements d'enseignement et de recherche français ou étrangers, des laboratoires publics ou privés. 
Risk Analysis of Ischemic-Type Biliary Lesions After Liver Transplant Using Octogenarian Donors

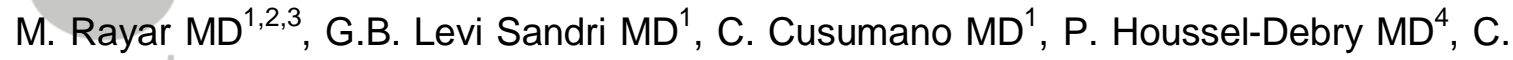

Camus MD PhD 2,5 , V. Desfourneaux MD¹, M. Lakehal MD¹, B. Meunier MD PhD ${ }^{1,3}$,

L.Sulpice MD PhD ${ }^{1,2,3}$, K. Boudjema MD PhD ${ }^{1,2,3}$

${ }^{1}$ CHU Rennes, Service de Chirurgie Hépatobiliaire et Digestive, F-35033 Rennes, France

2 INSERM, U1414, Centre d'investigation Clinique, F-35033 Rennes, France

${ }^{3}$ Université Rennes1, Faculté de médecine, F-35043 Rennes, France

${ }^{4}$ CHU Rennes, Service des maladies du foie, F-35033 Rennes, France

${ }^{5}$ CHU Rennes, Réanimation médicale, F-35033 Rennes, France

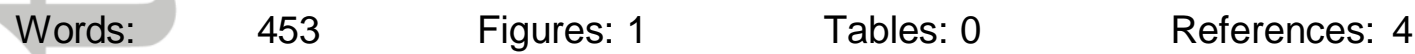

Keys words ; porto-caval shunt, liver transplantation, elderly donor, ECD graft

Corresponding author:

Michel Rayar

Service de Chirurgie Hépatobiliaire et Digestive, CHU de Rennes, Rennes, France

email: michel.rayar@chu-rennes.fr 


\section{Dear Editor,}

We read with great interest the study of Ghinolfi et al. entitled: "Risk Analysis of IschemicType Biliary Lesions After Liver Transplant using Octogenarian Donor" [1] and wanted to congratulate them for their work. The authors reported their series of 123 liver transplantations (LT), performed with the retro-hepatic inferior vena cava (IVC) replacement technique and veno-venous bypass, using octogenarian grafts and found that donor hemodynamic instability, diabetes mellitus and D-MELD were predictive of higher incidence of ischemic-type biliary lesions (ITBL) incidence in multivariate analysis.

In our center, we routinely perform LT with retro-hepatic IVC preservation and side-to-side cavo-caval anastomosis. According to surgeon preference, a temporary porto-caval shunt (TPCS) is performed or not. Since January 2007 to December 2014, 816 transplantations were performed in our institution and, using the same selection criteria as Ghinolfi et al., we identified 48 LT performed using octogenarian donors. TPCS was performed in 31 cases and absent in 17 cases.

We found that octogenarian graft survival was significantly improved when a TPCS was performed $(\mathrm{p}=0.02)$ (figure $1-\mathrm{A})$. We also observed a significant reduction of alkaline phosphatase and gamma-glutamyl transferase level in the early postoperative days (POD), while bilirubin levels were similar (figure 1-B,C,D).

The IVC preservation technique is currently preferred to the IVC replacement technique. In this situation, we found that use of TPCS improve octogenarian graft's outcome and biliary biological parameter in the early POD. Interest of TPCS has been previously shown [2] and some authors also reported improvement of long-term graft survival [3] but these results were not specifically focused on octogenarian graft. The benefit effects of TPCS might be explained by improvement of recipient's intraoperative hemodynamic status, 
decrease of post reperfusion syndrome incidence or prevention of splanchnic congestion [4].

In conclusion, we agree with Ghinolfi et al. regarding the safety of octogenarian graft and thought that TPCS should be recommended when vena cava preservation is performed, in order to improve outcomes and biliary function in this situation.

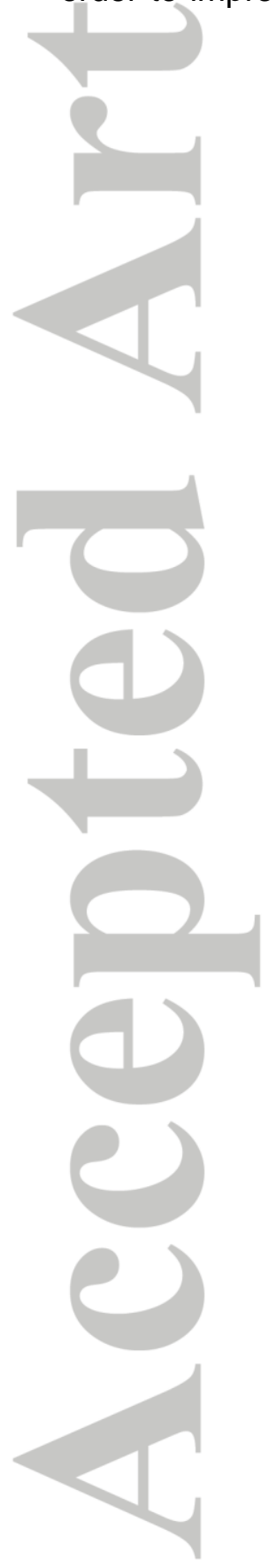




\section{References :}

1- Ghinolfi D, De Simone P, Lai Q, Pezzati D, Coletti L, Balzano E, et al. Risk Analysis of Ischemic-Type Biliary Lesions After Liver Transplant using Octogenarian Donors. Liver Transpl 2016.

2- Ghinolfi D, Martí J, Rodríguez-Laiz G, Sturdevant M, lyer K, Bassi D, et al. The beneficial impact of temporary porto-caval shunt in orthotopic liver transplantation: a single center analysis. Transpl Int. 2011 Mar;24(3):243-50.

3- Pratschke S, Meimarakis G, Bruns CJ, Kaspar M, Prix N, Zachoval R, et al. Temporary intraoperative porto-caval shunt: useless or beneficial in piggy back liver transplantation? Transpl Int. 2013 Jan;26(1):90-8.

4- Paugam-Burtz C, Kavafyan J, Merckx P, Dahmani S, Sommacale D, Ramsay M, et al. Postreperfusion syndrome during liver transplantation for cirrhosis: outcome and predictors. Liver Transpl 2009; 15: 522. 
Figures legends :

Figure 1: A-Octogenarian Graft survival according to use of temporary porto-caval shunt or not; B, C, D: Postoperative evolution of biological biliary parameter of octogenarian graft. The difference is statistically significative for alkaline phosphatase (ALP) level since postoperative day (POD) 0 and gamma-glutamyl transferase (GGT) level since POD 6, but not for bilirubin level.

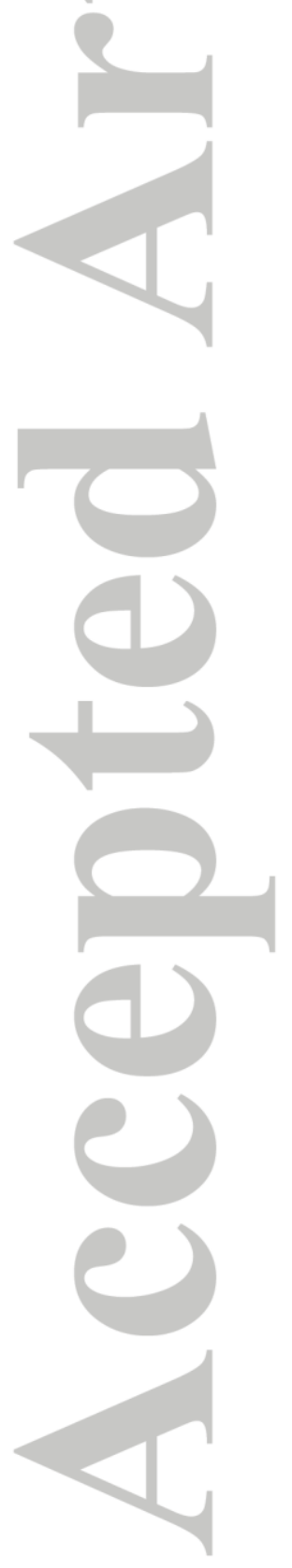



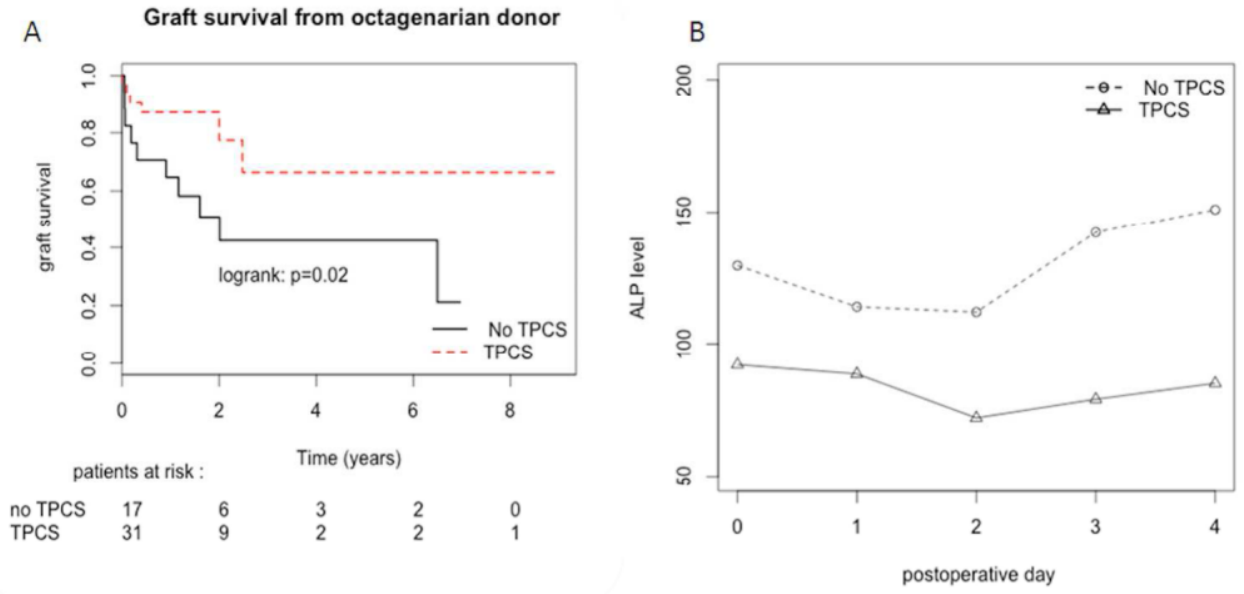

C
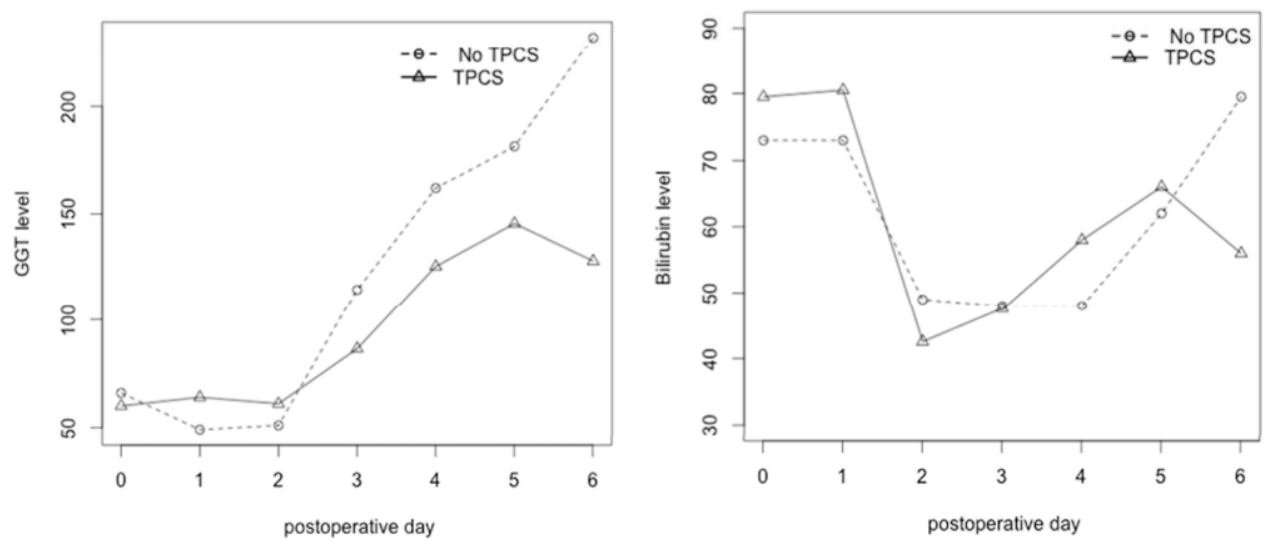

Figure 1: A-Octogenarian Graft survival according to use of temporary porto-caval shunt or not. \n B, C, D: Postoperative evolution of biological biliary parameter of octogenarian graft. The difference is statistically significative for alkaline phosphatase (ALP) level since postoperative day (POD) 0 and gamma-glutamyl transferase (GGT) level since POD 6, but not for bilirubin level.

$255 \times 251 \mathrm{~mm}(300 \times 300 \mathrm{DPI})$ 